\title{
PVAによる水の過冷却解消抑制効果の定量的評価
}

\section{Quantitative evaluation of inhibition effect of PVA on release of supercooling state of water}

\author{
武田 修太朗・信州大学 \\ Shutaro TAKEDA, Shinshu Univ. \\ 平田哲夫・信州大工 \\ Tetsuo HIRATA, Shinshu Univ.
}

熊野 筧之・信州大工

Hiroyuki KUMANO, Shinshu Univ.

工藤 智也 ・信州大院

Tomoya KUDOH, Shinshu Univ.

Key Words: Freezing, Supercooling, Water, PVA

\section{1. 緒論}

ダイナミック型水蓄熱システムなどで利用されるアイス スラリーの生成法の一つとして, 调泠却定用いて生成古る方

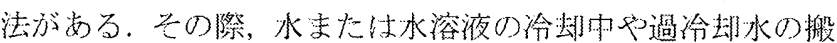
送中に不測の過冷却解消が起こると，配管の閉塞を引き起こ し，システム学安全に運檕することができなくなってしまう。 そのため, 現状で伎過冷度は2Kから $3 \mathrm{~K}$ 程撮とされている。 しかしながら，さらに薢い過泠度でシステムを安全に遭転で きれば，製氷速度の向上が期街できる。

ポリビニルアルコール（PVA）には，融点以下の温度にお

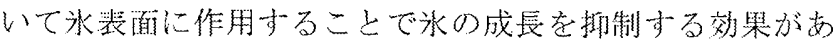
ることが知られている(1),(2)。この效果を利用小ることに上り，

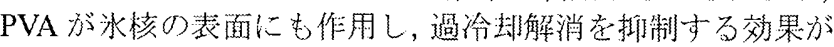
期街できる。乙こで本研炾では，PVAの重會度，け九化率を バラメータとして,PVA 死添加した水についての体積変化の 影響について具験的に検㢦を行う。さらに，確率的な現象で ある過冷却解消について統計的な処理を行い，通喻却解消温 度の予测李るための PVAの效果を定翼的に評価し，PVA が

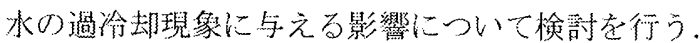

\section{2. 実験}

2-1 実験装置及び実験方法 図 1 に実験装犆の概略図を示

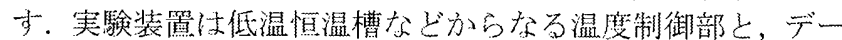
タロガーなどからなる温度測定部からなる。实験手順しして は, PVA 要溶解させた苚料芏ボリブロピレン製の試験管に入 れ，その後実験中のほこりなよ゙の䀝入により，寒験への影響

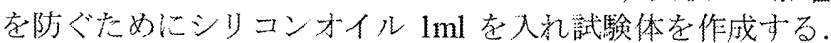
この䟼験体孛低温桓温槽内のブラインの中に浸し，ブライン の潈度老 $0.2 \mathrm{~K} / \mathrm{min}$ の一定速度で椧却し, 過冷却が解消寸る

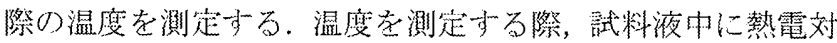

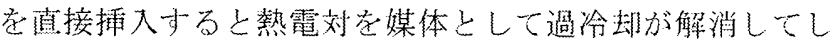

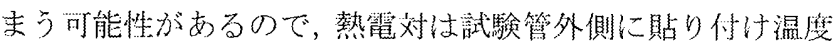
を測定した。ここで，凝固点から過泠却が解消した温度との 温度差至過泠却解消過渝度七寸る。

過洽却解消は確率的な現象であり，同じ条件で叜駼学行っ ても，各訨験体で過椧却解消する温度は琵なることから，同

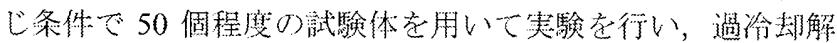

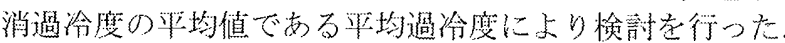

2-2 実験試料 本実験では，ポリビニルアルコール (PVA) を水に添加して実験をおこなった.PVAは親水性のヒドロキ

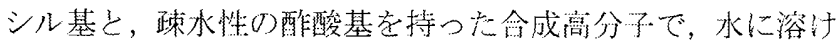
る性筫を毛っている。束た，分子の長さを示吉重合度とヒド ロキシル基の割合を示すけん化㻭により，その特性が変化す る。关こで本策験では，水に添加古るPVAの重合㦄之けん

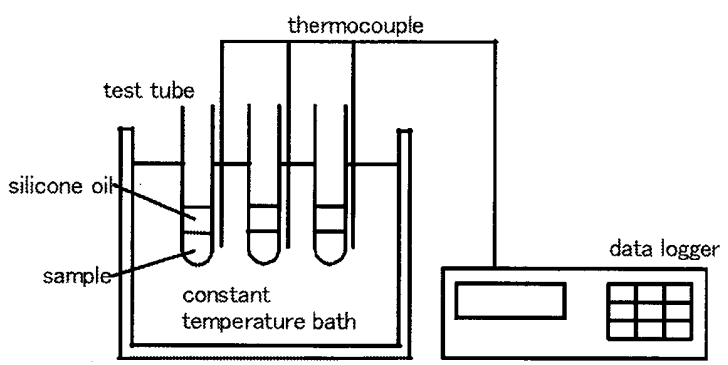

Fig.1 Experimental apparatus

化率を変化させて检詮を行った.PVA 溶解させる溶媒とし $\tau$, 比抵抗值 $1.2 \mathrm{k} \Omega \cdot \mathrm{cm} \sigma$ 水道水, 比抵抗值 $0.1 \mathrm{M} \Omega \cdot \mathrm{cm}$ の純 水打上ざ比抵抗值 $18.2 \mathrm{M} \Omega \cdot \mathrm{cm}$ の超純水を用いた. PVA 在浴 解する際，PVAを溶媒に添加した後，95Cまで加熱し，3時

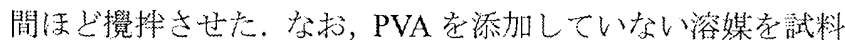

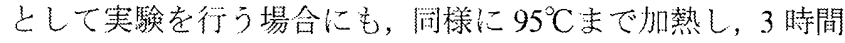

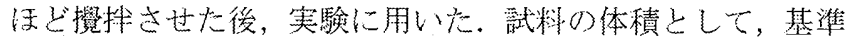

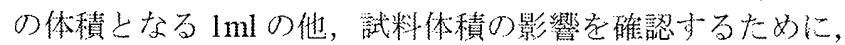
$0.2 \mathrm{ml}$ および $5 \mathrm{ml}$ の試料を用いて実驗を行った。

\section{3. 結果と考察}

3-2 実験結果の解析方法 従來の研究より，基準体積，基

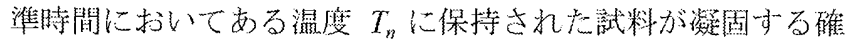
率を $W_{n}$ とすると，一定速度で冷却された時にある温度で凝

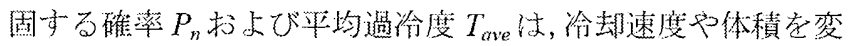
化させた場合にも, 次式で予測できることが知られている(3).

$$
\begin{aligned}
& P_{n}=\left(1-W_{1}\right)^{i a}\left(1-W_{2}\right)^{t a} \ldots\left[1-\left(1-W_{n}\right)^{t a}\right] \\
& T_{\text {que }}=\sum_{i=1}^{\max } T_{i} P_{i}
\end{aligned}
$$

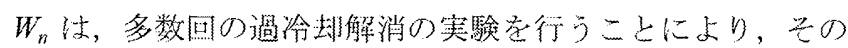

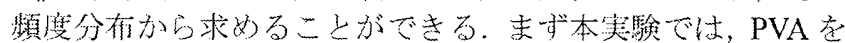
添加した場合にも，上式が利用できることを磼諗する。さら に, PVAの墖冷却解消抑制效果芫定量的に表小パラメー夕と して $\alpha$ 定戔し, PVA 老添加しない場合の $W_{n}$ から PVAを添

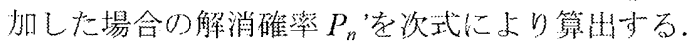

$$
P_{n}^{\prime}=\left(1-W_{1}\right)^{\frac{t a}{\alpha}}\left(1-W_{2}\right)^{\frac{t a}{\alpha}} \ldots\left[1-\left(1-W_{n}\right)^{\frac{t a}{\alpha}}\right]
$$

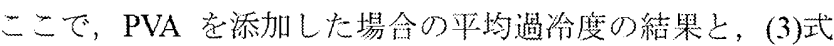

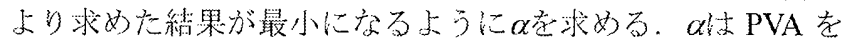
添加していない場合が 1 となり，值が大きくなる程，過泠却 解消の抑制効果名滈くなる。 


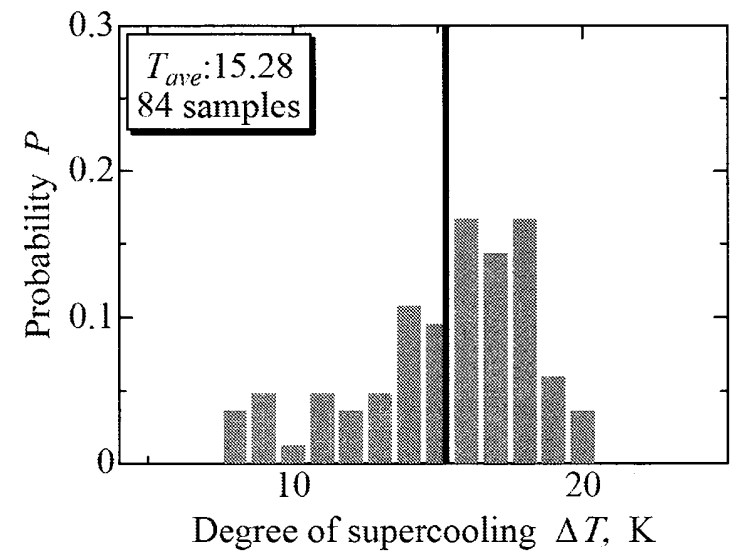

Fig.2 Probability distribution of the degree of supercooling

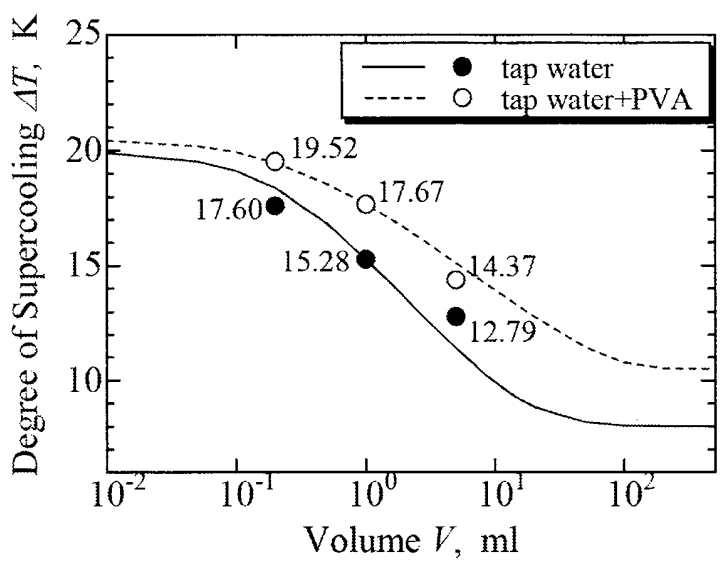

Fig. 3 Effect of volume on the average degree of supercooling

3-2 過冷却解消過冷度に対する体積の影響 PVA 添加し た際の影䬸を比較するために，ますPVA を添加していない 場合で実唤を行った，図 2 に一例として水道水 $\mathrm{Iml}$ における

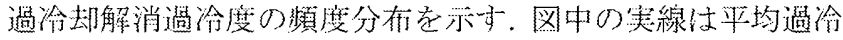

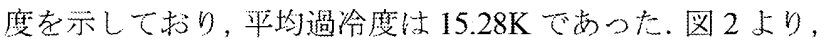

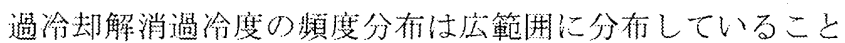

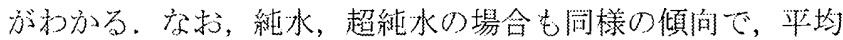

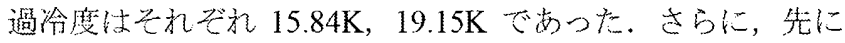
示した解析方法在用いて体積 $1 \mathrm{ml}$ の場合の頻度分布加ら体 積を変化させた場合の平均過冷剫の計算值上, 体積を $0.2 \mathrm{ml}$

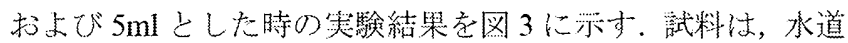
水上重會度 500 , け九化率 $88 \%$ の PVA 老添加した水道水であ る. 図上り，実験緹果方扮㧍上之解析絬果上一致し，PVA 添加した場合にも，徉来の解析方法が適明できることがわか る。文た，体積が大きくなるほよ゙，添加しない場合との善が 大きくなることから，PVAの效果江大きくなることがわかる。

3-3 重合度の影響 重合度を 300 から 3500 の範囲で 6 種類 の PVA 学水道水, 純水抢上び超純水に添加した場合の, 重 合度の影淛について比較を行った。忛人化率を $88 \%$, 添加卞 る濃度を $3 \mathrm{wt} \%(\vartheta$ 一定として重合度の力变化させた，重合

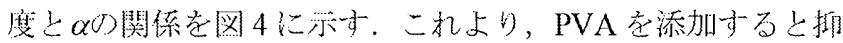

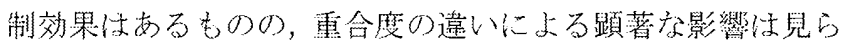
れないことがわかる。

3-4 けん化率の影響 汁九化率を $72 \%$ から $99 \%$ の範因で5 種類のPVA学水道水, 純水沶上び超純水に添加した場合の,

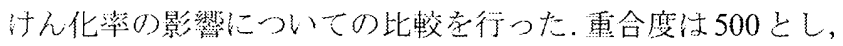

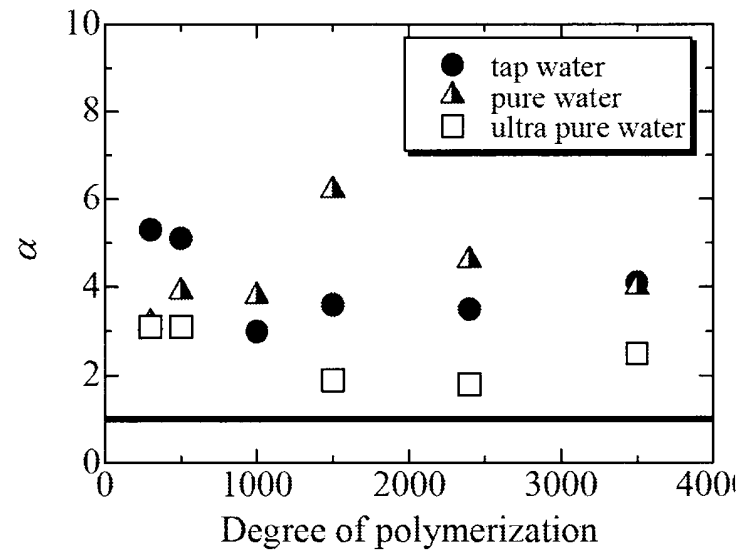

Fig.4 Effect of degree of polymerization

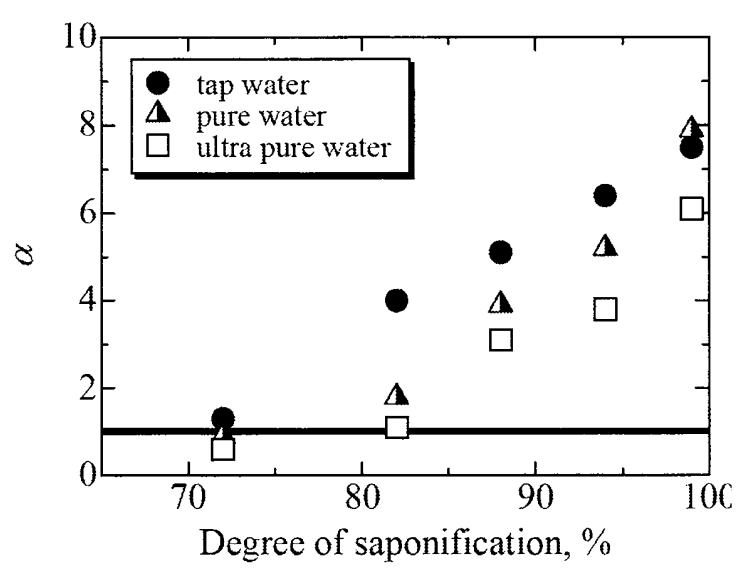

Fig. 5 Effect of degree of saponification

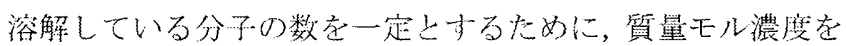

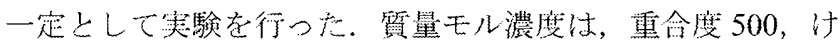
九化率 $88 \%$ O PVA を 3wt\%添加したとときに相当する 1.26

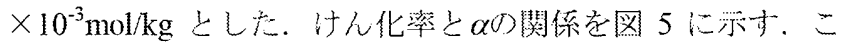
れより，けん化率が大きくなる伍ど肪大きくなり PVAの効 果が大きくなっていることがわかる。吏た純度が低くなるに

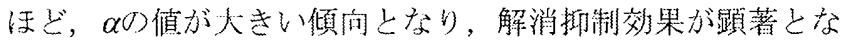

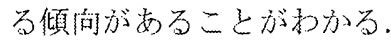

\section{4. 結論}

本研究で生，PVA を添加した水の過泠却解消抑制効果堂定 量的に評洒し，PVAの熏合度，けル化率などの影響について

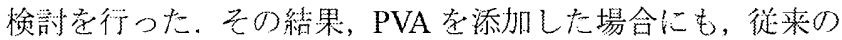
統計的処理が適用できるここがわかった，さらに，定黨的に 評価するためのバラメー夕を定義し，承の純度，重會度扰上 びけん化㻭を変化させた埸合の㧕制效果を明らかとした。

\section{参考文献}

(1) T.Inada, S. - S.Lu, Chemical Physics Letters, 394, 361(2004)

(2) 熊野筧之, 斎藤涁与, 大洞誠可, 滝溥至, 泠空論 24(4), 331(2007)

(3) 大河誠司, 斎藤樹大, 玲論 14(3), 293(1997) 